\title{
Does residential mobility improve educational outcomes? Evidence from the Netherlands
}

Citation for published version (APA):

Haelermans, C., \& De Witte, K. (2015). Does residential mobility improve educational outcomes? Evidence from the Netherlands. Social Science Research, 52(1), 351-369.

https://doi.org/10.1016/j.ssresearch.2015.02.008

Document status and date:

Published: 01/07/2015

DOI:

10.1016/j.ssresearch.2015.02.008

Document Version:

Publisher's PDF, also known as Version of record

Document license:

Taverne

Please check the document version of this publication:

- A submitted manuscript is the version of the article upon submission and before peer-review. There can be important differences between the submitted version and the official published version of record.

People interested in the research are advised to contact the author for the final version of the publication, or visit the DOI to the publisher's website.

- The final author version and the galley proof are versions of the publication after peer review.

- The final published version features the final layout of the paper including the volume, issue and page numbers.

Link to publication

\footnotetext{
General rights rights.

- You may freely distribute the URL identifying the publication in the public portal. please follow below link for the End User Agreement:

www.umlib.nl/taverne-license

Take down policy

If you believe that this document breaches copyright please contact us at:

repository@maastrichtuniversity.nl

providing details and we will investigate your claim.
}

Copyright and moral rights for the publications made accessible in the public portal are retained by the authors and/or other copyright owners and it is a condition of accessing publications that users recognise and abide by the legal requirements associated with these

- Users may download and print one copy of any publication from the public portal for the purpose of private study or research.

- You may not further distribute the material or use it for any profit-making activity or commercial gain

If the publication is distributed under the terms of Article $25 \mathrm{fa}$ of the Dutch Copyright Act, indicated by the "Taverne" license above, 


\title{
Does residential mobility improve educational outcomes? Evidence from the Netherlands is
}

\author{
Carla Haelermans ${ }^{\mathrm{a}, *}$, Kristof De Witte ${ }^{\mathrm{a}, \mathrm{b}}$ \\ ${ }^{a}$ Top Institute for Evidence-Based Education Research, Maastricht University, The Netherlands \\ ${ }^{\mathrm{b}}$ Faculty of Business and Economics, KU Leuven, Belgium
}

\section{A R T I C L E I N F O}

\section{Article history:}

Received 5 August 2013

Revised 13 February 2015

Accepted 18 February 2015

Available online 5 March 2015

\section{Keywords:}

Residential mobility

Secondary education

School dropout

Matching analysis

\begin{abstract}
A B S T R A C T
This paper explores the impact of residential mobility on educational outcomes. By considering a large Dutch city with substantial internal residential mobility, we examine how residential mobility influences the decision of students to drop out of school. The paper exploits a rich administrative dataset with extensive information on educational, individual, family, housing and moving characteristics of students. It combines a matching design with a multivariate regression analysis, such that the evaluation draws on a well-comparable control group for the treated students. Accounting for individual, family, educational, neighborhood and housing characteristics, as well as for school and year fixed effects, we observe that residential mobility increases the probability of school dropout in the first few years after moving. The estimated effect changes, however, to a lower risk of early school leaving after an initial period, and then changes again to a higher risk after 6 years. This effect remains, regardless the level of education the students attended, or whether the student moves to a better or a worse neighborhood.
\end{abstract}

(c) 2015 Elsevier Inc. All rights reserved.

\section{Introduction}

Residential mobility is a frequently occurring phenomenon, which might take place due to several reasons, such as change of jobs, marriage or divorce, addition to the family, or simply because people want a large house. Previous literature has shown that people's economic situation or education level influences residential mobility, welfare and other forms of social mobility (Boschma and Fritsch, 2009; Haveman and Smeeding, 2006 and references therein). However, the effect of residential mobility on educational outcomes attracted only limited attention of scholars. This is mainly due to serious methodological issues. Measuring the causal effect of residential mobility on (educational) outcomes is for most settings difficult due to endogeneity issues arising from unobserved characteristics. The latter arise as individuals with residential mobility are likely to have other (observed and unobserved) characteristics and backgrounds compared with individuals without social mobility. By exploiting a setting in which residential mobility can be naturally observed and in which a proper control group can be defined, this paper constructs evidence on the causal effect of social mobility on educational outcomes.

The literature makes a distinction along different types of social mobility, including intergenerational mobility (e.g. Checci and Flabbi, 2007; Werfhorst van de, 2002), occupational mobility (e.g. Kambourov and Manovskii, 2009), financial mobility

\footnotetext{
The authors would like to thank participants from the 2012 TIER lunch seminars, the 2012 ZEW workshop on Education and Equality of Opportunity and the Second Lisbon Research Workshop on Economics, Statistics and Econometrics of Education 2013, for their useful comments on previous versions of this article.

* Corresponding author.

E-mail addresses: carla.haelermans@maastrichtuniversity.nl (C. Haelermans), k.dewitte@maastrichtuniversity.nl (K. De Witte).
} 
(e.g., thanks to winning lotteries), intellectual mobility (e.g. Burt, 2011) or residential mobility (e.g. Gasper et al., 2010). This paper focuses on the influence of residential mobility on education outcomes. Earlier literature is inconclusive on the sign and magnitude of this effect, mainly because the reasons for residential mobility are diverse. Positive effects of residential mobility on education have been related to the upward economic mobility after World War II (Gasper et al., 2010; Rossi, 1955), whereas harmful effects are argued to be caused by 'forced' mobility due to unstable families and divorce (Amato, 2000; McLanahan and Sandefur, 1994; Morrison and Coiro, 1999; Speare et al., 1975). Besides on education, the impact of residential mobility has been explored on health (Larson et al., 2004) and adolescent delinquency (Gasper et al., 2010), for which in both cases negative correlations have been observed. Using the longitudinal data of the National Education Longitudinal Study (NELS), Swanson and Schneider (1999) made a distinction between residential mobility and school mobility. They observed that both residential and school mobility are associated with higher rates of early high school dropout.

Earlier literature on the influence of residential mobility on educational outcomes has some serious flaws which this paper aims to tackle. First, endogeneity issues arise in many studies as social mobility and educational outcomes might be affected by common unobserved characteristics (see e.g. Gasper et al., 2010). In other words, residential mobility is not random among individuals. Tucker et al. (1998) avoid this endogeneity issue by making the analysis conditional on the family structure (e.g., divorced, two-parents). In doing so, they assume that the reason for the move is homogeneous within a family type. In contrast with Tucker et al. (1998), our study accounts for non-random residential mobility by conditioning on a wide set of individual and family characteristics in a matching design. This is a more comprehensive approach as we include all households who move in a certain year (and thus avoid selection and the necessity of strong underlying assumptions) and construct a proper control group such that the results can be interpreted in a causal way.

More precisely, to identify the effect of residential mobility on educational outcomes, we proceed in two steps. In a first step, we construct for the students with residential mobility in 2005 (i.e., treated students) a matched sample of students without residential mobility (i.e., untreated students). By matching on a wide range of observed characteristics from a rich data set, we argue that also the unobserved characteristics are similar for the matched sample. In a second step, we estimate by a simple multivariate regression analysis how the treatment status influences the education outcome status. The identification strategy allows us to study the following research question: Are the education outcomes for students with residential mobility different from the counterfactual students in the matched control group?

A second issue in the previous literature arises from the diversity of educational outcomes. This study focuses on educational failure as an outcome. School dropout has been an important issue in national and international politics over the past decennium as it is a clear signal of an incomplete educational process. Within Western countries, governments aim for a significant reduction of early school leaving (e.g., The Horizon2020 Agenda within the EU, the No Child Left Behind Act in the US). By focusing on early school leaving as an outcome variable, we study the most disadvantaged students who are heavily 'at risk'. For similar people with poor educational outcomes, the influence of social mobility can be most prevalent. Due to our focus on school dropout, the paper is close to earlier work by Astone and McLanahan (1994) who explored to which extent residential mobility among non-intact families leads to school dropout. They observed that "as much as $30 \%$ of the difference in the risk of dropping out between children from stepfamilies and children from intact families can be explained by differences in residential mobility" (p. 576). Our paper differs from Astone and McLanahan (1994) as we do not focus on households with negative decisions for residential mobility (e.g., due to a divorce), but on the contrary on both negative and positive decisions for residential mobility. We argue below that we can make this distinction by exploiting mobility in a city with clear and strong internal migration patterns.

Third, social mobility in general and residential mobility specifically are often imprecisely measured in the previous literature, giving rise to measurement errors. This paper draws on rich and unique administrative data, including neighborhood and housing information (e.g., house value and ownership). The advantage of focusing on residential mobility is that for each student a sound and uniform definition of social mobility emerges. Moreover, the data arise from a new town (i.e., a town specially constructed for low and medium income households at commuting distance of a large town) in which residential mobility is common and highly valued. Moving to another neighborhood with higher housing values is in the case of this new town perceived as an improvement in social hierarchy and, thus could be perceived as upward mobility (see Section 3 for a discussion).

We believe that residential mobility can change educational outcomes in the short run (i.e., reduce early school leaving) by three mechanisms. First, by moving to a new neighborhood, the student experiences the influence of new peers (see literature on peer and neighborhood effects, e.g. Black et al., 2010; Clark et al., 2012; Sharkley, 2012; Sharkley and Elwert, 2011; Staff and Kreager, 2008), which can work both positive and negative, depending on where the student moves. Second, by moving to a different neighborhood, the direct shock of moving and large changes can increase the chance of dropout. On the other hand, depending on where the student moves, moving into a new neighborhood might also allow students to 'dream' about a better position in life, motivates them for schooling, and can trigger changes in the student's aspirations and behavior, which can have an influence on educational outcomes. In the long run, however, it could become clear that the better position in life that the student dreamt about is not happening, and the student could fall back to his/her old habits, regardless of the peers. Third, the decision to dropout may be motivated by the different skills associated with an education tract (e.g. vocational education, general education or pre-university education) and the labor market returns to those education tracts. As there is not much mobility between education tracts in the Netherlands, this lead to a negative effect of residential mobility.

The main outcomes of this paper indicate that, while controlling for individual, family, educational, neighborhood and housing characteristics, as well as for school and year fixed effects, we observe that residential mobility increases the risk 
of dropping out in the first few years after moving. This favorable outcome, however, changes to a lower probability of early school leaving as time passes, and changes back to a higher probability after six years. The effects are most visible for students that encounter only a little change in the housing value and the neighborhood characteristics. Our short term findings are in line with earlier work by Swanson and Schneider (1999) who observed that residential mobility increases dropout rates. Furthermore, we also find that in the long run residential mobility increases dropout rates again. Additional analyzes indicate that our results hold, regardless of whether the student has moved up or down (calculated by change of housing value), and for students in vocational and higher education. We do not find any results for students in primary and lower secondary education.

The remainder of this paper is structured as follows: Section 2 presents the literature and theoretical framework. Section 3 explains the Dutch educational system and the setting of this particular 'new town', which we exploit as a case for residential mobility. Section 4 describes the data, the indicators constructed from the data, and gives some descriptive statistics. Section 5 discusses the matching procedure and its use in the study at hand. Section 6 presents the results of the analysis and provides robustness analyzes. The paper ends with some concluding remarks and a discussion in Section 7.

\section{Literature and theoretical framework}

\subsection{Social mobility}

Social mobility is a broad concept that is used for many types of changes that increase or decrease the social status of an individual. The literature on social mobility falls apart into two strands. First, it examines what influences social mobility. Similar studies conclude that a higher educational degree increases social mobility (see overviews in Hensen et al., 2009; Machin et al., 2012; Malamud and Wozniak, 2008) and that higher transaction costs and inequality decrease social mobility (e.g. Ommeren van and van Leuvensteijn, 2005; Rodriguez et al., 2008; Schafft, 2006). A second, and more recent, research avenue examines the influence of social mobility on various outcomes. For example, in their quasi-experimental study, Gasper et al. (2011) argue that school dropout increases when students switch schools, even when controlling for negative individual characteristics. The paper at hand follows the latter strand of literature and specifically focuses on one aspect of social mobility, namely residential mobility.

\subsection{Residential mobility}

With respect to residential mobility, the most well-known research avenue was the 'moving to opportunity' experiment in the United States in the early nineties. This experiment created among 4600 low-income families three groups for which different types of housing vouchers were offered. A first group could use the housing voucher only in low-poverty areas. A second group was offered vouchers to move to any place they wanted, while a third (control) group did not receive housing vouchers. In the evaluation, the effect on housing, neighborhood conditions, physical and mental health, economic self-sufficiency, criminal behavior and educational outcomes was estimated (Sanbonmatsu et al., 2011). The results of the 'moving to opportunity' experiment reveal that there are hardly any effects on educational outcomes and some small (short term) effects on other youth outcomes (see e.g. Katz et al., 2001; Sanbonmatsu et al., 2006, 2011).

Another well-known residential mobility program is the 'Gautreaux Project', which is actually the forerunner of the moving to opportunity experiment (Hango, 2003; Keels, 2008a). The Gautreaux Project also was a randomized experiment, initiated by court order and aiming at housing-desegregation. Participants were offered placement in either city or suburban areas. Housing vouchers were provided to 7500 African American families, who could apply for the vouchers by calling in on a certain day. Applicants were screened based on apartment maintenance and criminal records and about two thirds of the applications were accepted. Because of this selection, there is a discussion in the literature on the true randomization of this experiment (Hango, 2003; Sampson et al., 2002). This program suggests that adults and youngsters who moved to suburban areas are significantly better off with respect to high school retention, grades, college attendance and wages (Kaufman and Rosenbaum, 1992), employment (Kaufman and Rosenbaum, 1992; Mendenhall et al., 2006), drug use (Keels, 2008b) and time on welfare and public assistance (Mendenhall et al., 2006; Rosenbaum and DeLuca, 2000).

\subsection{Motivation for residential mobility}

The choice to move can be motivated by several reasons. First, there might be opportunities in the housing market due to new construction, mortgage interest rates and tax reliefs (Clark and Dieleman, 1996; Dieleman, 2001; Myers, 1999). Particularly the new construction is relevant for this paper. Other motivations can be found in the chain migration theory (also called migration networks theory) according to which migrants follow migration paths of previous migrants in their network. The 'socialization' theory argues that the location of friends and family plays an important role, while the 'endogenous stigmatization' suggests that people move because of negative stereotyping of neighborhoods.

Speare (1974) argued that dissatisfaction is a necessary condition for moving (Heylen, 2007; Speare, 1974). The dissatisfaction might come from (1) the different needs of the real estate (Brown and Moore, 1970; Clark and Dieleman, 1996; Galster and Hedman, 2012; Speare et al., 1975) and, more importantly, (2) the neighborhood (Clark and Ledwith, 2006; Clark et al., 
2006; Feijten and Van Ham, 2009; Galster and Hedman, 2012; Ham van and Feijten, 2008; Hedman et al., 2011; Kearns and Parkes, 2003; Lee et al., 1994; Lu, 1998). Regarding the latter, the 'white flight' theory states that characteristics of other people in the neighborhood could cause individuals to move (Galster and Hedman, 2012). Another theory, similar to the 'white flight' theory is the 'white avoidance' theory (Ellen, 2000), in which individuals are unwilling to move into certain neighborhoods with a large share of other ethnicities. Also the changed composition of the neighborhood might trigger residential mobility. Feijten and van Ham (2009), Ham van and Clark (2009) and Ham van and Feijten (2008) argue that, if the ethnicity composition of a neighborhood changes, individuals from the decreasing ethnicity in the neighborhood have increasing moving wishes.

\subsection{Effects of residential mobility}

Residential mobility has been shown to influence various outcome variables. Galster and Hedman (2012) mention effects on employment, educational attainment (Crane, 1991; Crowder and South, 2011; Harding, 2003; Sykes and Musterd, 2011; Wodtke et al., 2011), income (Galster et al., 2010, 2008; Oreopoulos, 2003), cognitive development (Sampson et al., 2008) and crime (Kling et al., 2005).

Concerning health outcomes, Larson et al. (2004) suggest in their correlational study that residential mobility leads to long-term and poor chronic health, while Bartley and Plewis (2007) have shown, in their also correlational study, that social mobility between social classes reduces health inequalities. It further seems that social mobility leads to increased adolescent delinquency (Gasper et al., 2010), reduced social capital (Pettit and McLanahan, 2003), increased risk of drug use (DeWit, 1998) and behavioral problems (Hendershott, 1989; Norford and Medway, 2002; Wood et al., 1993). Note, however, that only the studies of Gasper et al., Pettit \& McLanahan and Norford \& Medway have a proper control group and correct for selection bias.

Concerning the effect of residential mobility on educational outcomes and drop out, we see that Gasper et al. (2011) find a positive relationship between school mobility and dropout in their quasi-experimental study, even when controlling for negative individual characteristics. However, the latter study studies they effect of school mobility, which is in most cases due to residential mobility, but not residential mobility directly. A correlational study on the effect of educational outcomes find, among others, that math and reading achievement is negatively influenced by residential mobility (Voight et al., 2012). Another study, using an Instrumental Variable approach, finds that high school graduation rates are also negatively influenced by residential mobility (Chen, 2013). Other studies, though a little older, and only correlational, find that residential mobility reduces educational attainment (Coleman, 1988; Hagan et al., 1996; Haveman et al., 1991).

\section{Setting}

\subsection{School dropout in the Netherlands}

In the Netherlands, pupils attend primary education between ages 4 and 12 and secondary education until a higher secondary degree is obtained. Fig. 1 depicts a self-constructed graphical representation of the Dutch educational system. One can distinguish five different levels of education: practical training education (pro), prevocational secondary education (vmbo), vocational education (mbo), general upper secondary education (havo) and pre-university education (vwo). Pupils enter a level of education in the first year of secondary education based on a standardized national test and a recommendation given in elementary school (i.e., ability tracking). Depending on the level of education, secondary education takes 4 (vmbo), 5 (havo) or 6 (vmbo-mbo; vwo) years to complete. As placement in tracts is merely based on a standardized test in primary school and the advice of the primary school teacher in the last primary school grade, there is not much mobility between education tracts.

In line with the European definition, a youngster below the age of 23 is considered as a school dropout if he or she is no longer in education and did not obtain a higher secondary degree (i.e., completes vwo or havo or at least finishes mbolevel2). In the Netherlands, 38,568 students dropped out of school during the school year 2010/2011. The municipality under study has one of the highest percentages of early school leavers (i.e., $4.1 \%$ of new early school leavers in $2010 / 2011$ in comparison with the national average of $2.9 \%$ ). The high numbers of early school leaving made European policy makers decide to make school dropout as one of the main priorities in the Horizon2020 targets. In the Netherlands, various policy interventions aim to reduce early school leaving (for a discussion of the interventions, see Cabus \& De Witte, 2015; De Witte and Cabus, 2013). ${ }^{1}$

\subsection{New town and its advantage for the identification}

The empirical application considers one municipality in the eastern region of Amsterdam. With a population of 195,000 inhabitants the municipality is the seventh largest Dutch municipality. The municipality makes an interesting case study as

\footnotetext{
${ }^{1}$ Note that as all policy measures are employed for both the control and the treatment group, the estimated effect is not biased by the introduction of policy measures.
} 


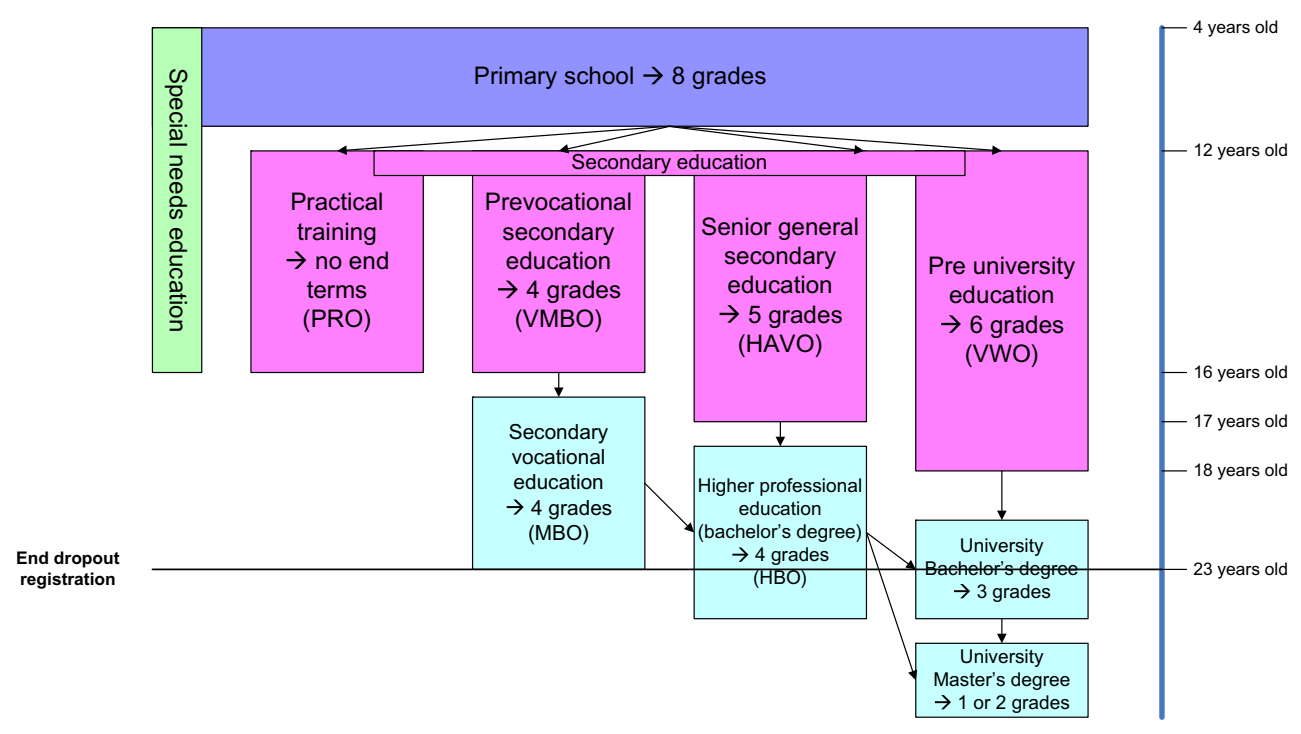

Fig. 1. The Dutch education system (self-constructed figure).

it has, due to historical reasons, a high internal residential mobility. The municipality belongs to the top 10 percent municipalities with respect to internal migration between 2005 and 2010 (CBS, 2012).

The municipality is a so-called new town, which are towns constructed to stop the suburbanization in the Netherlands after the Second World War. New towns are located at a short distance of large cities. The existence of these towns should stop housing and resources shortages and provide commuting possibilities to its residents (Hall and Tewder-Johnes, 2010). New towns are heavily subsidized by the government and the low and medium priced houses attracted the people that were targeted, namely the people with a vulnerable position in the housing market due to income, social or cultural skills (MinVROM, 2000). It are mainly low and middle income families that live in these new towns.

The municipality is a special new town as it is constructed in the artificial polders around the city of Amsterdam. Therefore it has a lot of space to construct new houses and neighborhoods. The older houses and neighborhoods especially target the lower income households, and have therefore rather basic constructions (e.g., flat roofs, all connected houses). The more recent houses target middle class income groups and are also constructed for this purpose (e.g., larger gardens, semiopen constructions). Given the status of the new neighborhoods, it is not surprising that moving towards the newer neighborhoods is perceived as upward social mobility, which in confirmed in the data by the higher average housing values in these neighborhoods.

Previous research has shown that new towns, similar to this one, have a population that does not constitute the average town population in the Netherlands. There is a larger share of immigrants, single parents, and lower educated parents (De Witte et al., 2015; Ledoux, 2011). This has consequences for the educational performance in these cities. Educational attainments are lower and dropout rates are higher than the Dutch average (Education Inspectorate, 2010). Although the population does not constitute the average population in the country, within 'new towns' the population is homogeneous with only minor differences in population characteristics, which makes it attractive for our analysis.

In the empirical application, we only consider residential mobility within this new town only. One reason for this is that we do not have data on the students that move outside this town. However, only considering within town mobility also has some clear advantages. First, we can make use of a treatment and control group which include comparable individuals with respect to educational level and social background (see De Witte et al., 2015 for a discussion). Moreover, it reduces unobserved heterogeneity as people move to other cities because of a variety of reasons (e.g., job market opportunities). Third, moving within the same municipality is rather exceptional in traditional municipalities, but a common way to express social mobility in new towns. Therefore, we can observe a clear signal for social mobility. Finally, given the scale of the municipality, most students do not change schools after they moved to a new house. This allows us to clearly distinguish the influence from residential mobility from school mobility.

\section{Data}

This study uses an unbalanced panel data set of 32,468 pupils at compulsory education age until 18 , between the school years 2005 and 2010. Because the registration of dropouts between 18 and 23 is often not very accurate (see Cabus and De Witte, 2011), we have decided to only include individuals up to the age of 18 (in 2005) in our analysis, making them a maximum of 23 years old in 2010. To causally identify the effect of residential mobility on educational outcomes, we construct a control and experimental group. Ideally, we randomly select households to move to a different neighborhood and compare 
Table 1

Descriptive statistics for the original sample in $2005 *$.

\begin{tabular}{|c|c|c|c|}
\hline & \multicolumn{3}{|l|}{2005} \\
\hline & $\begin{array}{l}D=0 \\
\text { Mean }\end{array}$ & $\begin{array}{l}D=1 \\
\text { Mean }\end{array}$ & $\begin{array}{l}D=1-D=0 \\
t \text {-Stat }\end{array}$ \\
\hline$N$ & 31,311 & 1157 & \\
\hline Dropout & 0.021 & 0.043 & -5.047 \\
\hline Age & 12.325 & 12.335 & -0.096 \\
\hline Gender ( 1 = female $)$ & 0.490 & 0.498 & -0.548 \\
\hline Family size & 3.968 & 3.768 & 5.921 \\
\hline Years in the Netherlands & 10.500 & 11.109 & -4.209 \\
\hline \multicolumn{4}{|l|}{ Ethnicity } \\
\hline Dutch & 0.588 & 0.589 & -0.083 \\
\hline Antillean & 0.031 & 0.040 & -1.615 \\
\hline Surinam & 0.129 & 0.148 & -1.869 \\
\hline Turkish & 0.023 & 0.020 & 0.602 \\
\hline Moroccan & 0.039 & 0.041 & -0.208 \\
\hline African & 0.031 & 0.022 & 1.686 \\
\hline Other non-Western & 0.068 & 0.060 & 1.147 \\
\hline Other Western & 0.079 & 0.080 & -0.137 \\
\hline Unknown & 0.011 & 0.000 & 3.548 \\
\hline \multicolumn{4}{|l|}{ Type of education } \\
\hline Unknown & 0.060 & 0.087 & -3.799 \\
\hline Special education & 0.440 & 0.449 & -0.630 \\
\hline Practical education & 0.040 & 0.037 & 0.539 \\
\hline Years 1 and 2 secondary education & 0.015 & 0.020 & -1.270 \\
\hline VMBO & 0.089 & 0.081 & 0.916 \\
\hline HAVO & 0.122 & 0.104 & 1.877 \\
\hline VWO & 0.054 & 0.048 & 0.803 \\
\hline MBO & 0.072 & 0.054 & 2.298 \\
\hline HBO & 0.095 & 0.108 & -1.446 \\
\hline Adult education & 0.012 & 0.010 & 0.476 \\
\hline Rental house & 0.277 & 0.347 & -4.882 \\
\hline Average housing value in neighborhood & 198798.5 & 205775.1 & -4.317 \\
\hline
\end{tabular}

* Dummies of 23 types of categories of instruction and 23 housing types also tested.

the dropout status of those children with the dropout status of children who were not assigned to a different neighborhood. This raises two issues. First, this would serve only as a proxy of mobility, not of residential mobility as the selected households would live in a new environment, such that they have, at best, only new neighbors and peers. Second, similar random assignment would be both expensive and raise ethical issues (cf. the 'moving to opportunity' experiment had a budget of 70 million dollar (Shroder, 2001)).

To avoid the drawbacks of a randomized controlled experiment, we make use of quasi-experimental evidence by constructing two groups for the base year 2005. A first group consists of pupils who moved to a different neighborhood within the new town, in 2005. A second group consists of students with similar observed characteristics as the students from the former group. Note that we only include individuals in the treatment group that have moved in 2005, who do not move again after 2005 and who have not moved in the four years previously to 2005 , so from $2001 \mathrm{on}^{2}$ For the control group, we also only allow individuals to be a control if they have not moved at all, between 2001 and 2010.

The data set include 1157 students in the first group. This corresponds to $3.5 \%$ of the data, which indicates (given the relatively short time span) the relatively high internal mobility in the new town. Because we would like to analyze both short term and longer term effects of residential mobility on dropout (up to six years later) we need to be able to follow all students for at least six years. Following the students for six years has two reasons. First, it might take some time for residential mobility to show effects. Using a time span of six years makes it also possible to study the effect of the elapsed time since one moved, which allows us to make a differentiation in time.

A disadvantage of the registration data that we used is that students who graduate or permanently drop out of school are not visible in the dataset anymore in the year after they have graduated or dropped out. However, this does not mean that they are not still a graduate or dropout in the year after. ${ }^{3}$ Therefore, the data are made balanced between 2005 and 2010 by creating duplicates for dropouts and graduates for the remaining years, based on the information in the latest year that we have data on. The municipality counts 3502 school dropouts in $2005 .^{4}$

\footnotetext{
${ }^{2}$ Note that we have data on moving from 1997 on, but only have data on dropout from 2005 on. This allows us to control for moving behavior in the years before the years that we use in our analysis.

${ }^{3}$ If they were no dropout in the year after anymore, they would appear again in the data.

${ }^{4}$ Note that, in line with the data collection procedure in the municipality, we follow a slightly different definition than the official Dutch definition. Where the official Dutch definition considers as early school leavers only students who dropped out in a given year, the official definition of the municipality also considers all students without a higher secondary degree not enrolled in education (independent of the year) as school dropout.
} 
Table 2

Probit regression on dummy residential mobility in 2005.

\begin{tabular}{|c|c|c|c|c|}
\hline Dummy residential mobility in 2005 & $\begin{array}{l}\text { Number of obs. }= \\
\text { LR chi2 }(59) \\
\text { Prob }>\text { chi2 }= \\
\text { Pseudo } R \text {-squared }= \\
\text { Coef. }\end{array}$ & Std. Err. & $\begin{array}{l}24,510 \\
0.000 \\
0.000 \\
0.025 \\
z\end{array}$ & $P>t$ \\
\hline Age 7 & -0.164 & 0.093 & -1.780 & 0.076 \\
\hline Age 8 & 0.000 & 0.086 & 0.000 & 1.000 \\
\hline Age 9 & -0.039 & 0.088 & -0.450 & 0.655 \\
\hline Age 10 & -0.072 & 0.092 & -0.790 & 0.429 \\
\hline Age 11 & 0.126 & 0.088 & 1.440 & 0.151 \\
\hline Age 12 & -0.013 & 0.106 & -0.120 & 0.901 \\
\hline Age 13 & -0.011 & 0.126 & -0.090 & 0.928 \\
\hline Age 14 & -0.054 & 0.130 & -0.410 & 0.679 \\
\hline Age 15 & -0.116 & 0.136 & -0.850 & 0.395 \\
\hline Age 16 & -0.154 & 0.144 & -1.070 & 0.285 \\
\hline Age 17 & -0.036 & 0.150 & -0.240 & 0.808 \\
\hline Age 18 & 0.128 & 0.155 & 0.830 & 0.407 \\
\hline Gender $(1=$ female $)$ & 0.015 & 0.029 & 0.520 & 0.601 \\
\hline Family size & -0.068 & 0.014 & -4.900 & 0.000 \\
\hline Years in the Netherlands & -0.033 & 0.006 & -5.660 & 0.000 \\
\hline Type of education 1 & 4.249 & 0.769 & 5.530 & 0.000 \\
\hline Type of education 2 & 4.300 & 0.731 & 5.880 & 0.000 \\
\hline Type of education 3 & 3.717 & 0.286 & 12.980 & 0.000 \\
\hline Type of education 4 & 4.045 & 0.207 & 19.550 & 0.000 \\
\hline Type of education 5 & 4.566 & 0.702 & 6.500 & 0.000 \\
\hline Type of education 6 & 3.964 & 0.288 & 13.750 & 0.000 \\
\hline Type of education 7 & 3.788 & 0.184 & 20.580 & 0.000 \\
\hline Type of education 8 & 3.663 & 0.190 & 19.250 & 0.000 \\
\hline Type of education 9 & 3.696 & 0.180 & 20.490 & 0.000 \\
\hline Type of education 10 & 3.766 & 0.261 & 14.440 & 0.000 \\
\hline Type of education 11 & 3.983 & 0.241 & 16.500 & 0.000 \\
\hline Type of education 12 & 3.861 & 0.287 & 13.430 & 0.000 \\
\hline Type of education 13 & 3.726 & 0.198 & 18.850 & 0.000 \\
\hline Type of education 14 & 3.739 & 0.250 & 14.960 & 0.000 \\
\hline Type of education 15 & 3.803 & 0.227 & 16.760 & 0.000 \\
\hline Type of education 16 & 0.189 & 0.207 & 0.910 & 0.362 \\
\hline Type of education 17 & 3.628 & 0.172 & 21.130 & 0.000 \\
\hline \multicolumn{5}{|l|}{ Ethnicity } \\
\hline Antillean & -0.075 & 0.086 & -0.870 & 0.385 \\
\hline Surinam & -0.016 & 0.047 & -0.340 & 0.732 \\
\hline Turkish & -0.042 & 0.109 & -0.390 & 0.696 \\
\hline Moroccan & 0.035 & 0.081 & 0.430 & 0.669 \\
\hline African & -0.121 & 0.093 & -1.300 & 0.192 \\
\hline Other non-Western & -0.123 & 0.066 & -1.880 & 0.060 \\
\hline Other Western & -0.039 & 0.056 & -0.690 & 0.493 \\
\hline \multicolumn{5}{|l|}{ Type of education } \\
\hline Special education & -0.169 & 0.253 & -0.670 & 0.505 \\
\hline Practical education & -0.853 & 0.701 & -1.220 & 0.224 \\
\hline Years 1 and 2 secondary education & -0.139 & 0.269 & -0.520 & 0.606 \\
\hline VMBO & (omitted) & & & \\
\hline HAVO & (omitted) & & & \\
\hline VWO & 0.137 & 0.090 & 1.520 & 0.129 \\
\hline МВO & (omitted) & & & \\
\hline HBO & 0.050 & 0.116 & 0.430 & 0.664 \\
\hline Adult education & 3.395 & 0.200 & 17.010 & 0.000 \\
\hline Housing type 1 & 0.067 & 0.207 & 0.320 & 0.746 \\
\hline Housing type 2 & -0.051 & 0.465 & -0.110 & 0.912 \\
\hline Housing type 3 & -0.209 & 0.433 & -0.480 & 0.629 \\
\hline Housing type 4 & 0.130 & 0.134 & 0.970 & 0.332 \\
\hline Housing type 5 & 0.171 & 0.107 & 1.610 & 0.108 \\
\hline Housing type 6 & 0.119 & 0.098 & 1.220 & 0.222 \\
\hline Housing type 7 & -0.083 & 0.256 & -0.320 & 0.747 \\
\hline Housing type 8 & 0.276 & 0.127 & 2.160 & 0.030 \\
\hline Housing type 9 & 1.329 & 0.771 & 1.720 & 0.085 \\
\hline Housing type 10 & 0.500 & 0.180 & 2.780 & 0.005 \\
\hline Housing type 11 & 0.172 & 0.089 & 1.930 & 0.053 \\
\hline Housing type 12 & 0.018 & 0.072 & 0.250 & 0.805 \\
\hline
\end{tabular}


Table 2 (continued)

\begin{tabular}{|c|c|c|c|c|}
\hline Dummy residential mobility in 2005 & $\begin{array}{l}\text { Number of obs. }= \\
\text { LR chi2(59) } \\
\text { Prob }>\text { chi } 2= \\
\text { Pseudo } R \text {-squared= } \\
\text { Coef. }\end{array}$ & Std. Err. & $\begin{array}{l}24,510 \\
0.000 \\
0.000 \\
0.025 \\
z\end{array}$ & $P>t$ \\
\hline Housing type 13 & 0.061 & 0.064 & 0.950 & 0.341 \\
\hline Housing type 14 & 0.310 & 0.501 & 0.620 & 0.537 \\
\hline Housing type 15 & 0.041 & 0.087 & 0.470 & 0.638 \\
\hline Rental house & 0.140 & 0.038 & 3.650 & 0.000 \\
\hline Average housing value in neighborhood & 0.000 & 0.000 & 6.050 & 0.000 \\
\hline Constant & -5.098 & 0.215 & -23.680 & 0.000 \\
\hline
\end{tabular}

To increase the efficiency of the estimates and to correct for observed heterogeneity, the analysis includes various covariates. Some descriptive statistics are presented in Table 1. For each covariate, Table 1 presents the descriptive statistics for households with $(D=1)$ and without $(D=0)$ residential mobility in 2005 . Moreover, Table 1 provides by simple $t$-tests statistical information on the comparability of the treatment and control group in 2005. Despite that all students originate from the same homogeneous municipality, the majority of the variables are significantly different between the two groups, which underlines the necessity for constructing a matched sample. In line with previous literature (e.g. De Witte and Rogge, 2012 and references therein) we observe that category of instruction (i.e. the level of education a student attains in a given year), age, gender, family size, number of residency years in the Netherlands, and some types of ethnicity and types of education differ for students with residential mobility. Also the type of house people live in differs significantly between the treated and non-treated students. In the base year 2005, school dropout is (on face value for the unmatched sample) significantly higher for students with residential mobility (4.3\% versus $2.1 \%$ ). Students in the treatment group are also slightly older and there are more females in this group.

This finding is confirmed by a Probit regression, which correlates residential mobility with various observed characteristics. The Probit outcomes, presented in Table 2, indicate the probability of residential mobility. The results suggest that residential mobility is not random among the population, which is in line with the motivational factors for residential mobility in the theoretical framework. ${ }^{5}$ To mitigate the impact of observed (and unobserved characteristics), all variables with significant differences in Tables 1 and 2 are included in a matching procedure in order to make the treatment and control group better comparable.

\section{Matching procedure and identification strategy}

\subsection{Constructing a valid reference group}

The previous section indicated that there are differences in category of instruction, age, gender, family size, number of residency years in the Netherlands, and some types of ethnicity and education between students with and without a residential move. These differences might bias the analysis. To avoid this pitfall, we use a nearest neighbor (NN) matching procedure to identify for each student in the treatment group a similar student in the control group. Note that alternative matching procedures as Iterative Matching, Kernel Matching and Mahalanobis matching delivered similar outcomes. The underlying assumption is that by matching on a wide range of observed variables, similarities between the two groups arise on also the unobserved variables.

The matching procedure searches for every student with residential mobility the best look-alike student without residential mobility, based on a vector of observable background characteristics $x .{ }^{6}$ The background characteristics on which we match are similar to the covariates described in the data section. We use matching without replacement due to the large sample size. Let $N_{\mathrm{M}}$ and $N_{\mathrm{NM}}$ denote the number of students that have moved (M) and the number of students that have not moved $(\mathrm{NM})$, respectively. The matching approach assigns weights to the $j$-th observation, that could serve as a potential match for the $i$-th moving observation. The weight-function is denoted by $w(i, j)$ with $\sum_{j} w(i, j)=1$. The matching estimator of the average treatment effect on the treated (ATT) is then:

$$
\Delta=\frac{1}{N_{\mathrm{M}}} \sum_{i \in[I=1]}\left[y_{1, i}-\sum_{j} w(i, j) \cdot y_{0, j}\right],
$$

where $w(i, j)=1, I=1$ is the set of moving students and $j$ is a non-moving student of the set of regular students.

Where the descriptive statistics in Table 1 are based on the original underlying data, the descriptive statistics in Table 3 are based on the matched samples. From Table 3 one learns that the matching procedure has succeeded as none of the characteristics of the individuals are now significantly different between the treatment and control group. In other words, the

\footnotetext{
5 Unfortunately we do not have information on the parents' education, to include in the analysis.

6 This section is based on De Witte et al. (2015) and Cameron and Trivedi (2005).
} 
Table 3

Descriptive statistics for the matched sample in $2005^{*}$.

\begin{tabular}{|c|c|c|c|}
\hline & \multicolumn{3}{|l|}{2005} \\
\hline & $\begin{array}{l}D=0 \\
\text { Mean }\end{array}$ & $\begin{array}{l}D=1 \\
\text { Mean }\end{array}$ & $\begin{array}{l}D=1-D=0 \\
t-\text { Stat }\end{array}$ \\
\hline$N$ & 1016 & 1016 & \\
\hline Dropout & 0.028 & 0.043 & -1.921 \\
\hline Age & 12.115 & 12.307 & -1.169 \\
\hline Gender ( 1 = female) & 0.486 & 0.499 & -0.577 \\
\hline Family size & 3.719 & 3.759 & -0.778 \\
\hline Years in the Netherlands & 11.092 & 11.174 & -0.446 \\
\hline \multicolumn{4}{|l|}{ Ethnicity } \\
\hline Dutch & 0.607 & 0.605 & 0.091 \\
\hline Antillean & 0.042 & 0.037 & 0.567 \\
\hline Surinam & 0.148 & 0.139 & 0.570 \\
\hline Turkish & 0.014 & 0.019 & -0.877 \\
\hline Moroccan & 0.038 & 0.037 & 0.116 \\
\hline African & 0.020 & 0.026 & -0.895 \\
\hline Other non-Western & 0.058 & 0.060 & -0.188 \\
\hline Other Western & 0.073 & 0.077 & -0.337 \\
\hline Unknown & 0.000 & 0.000 & 0.000 \\
\hline \multicolumn{4}{|l|}{ Type of education } \\
\hline Unknown & 0.082 & 0.088 & -0.478 \\
\hline Special education & 0.482 & 0.457 & 1.156 \\
\hline Practical education & 0.039 & 0.035 & 0.468 \\
\hline Years 1 and 2 secondary education & 0.019 & 0.019 & 0.000 \\
\hline VMBO & 0.080 & 0.083 & -0.244 \\
\hline HAVO & 0.090 & 0.101 & -0.906 \\
\hline VWO & 0.043 & 0.048 & -0.531 \\
\hline MBO & 0.047 & 0.054 & -0.708 \\
\hline HBO & 0.110 & 0.106 & 0.285 \\
\hline Adult education & 0.008 & 0.009 & -0.243 \\
\hline Rental house & 0.369 & 0.347 & 1.018 \\
\hline Average housing value in neighborhood & 208664.1 & 209475.3 & -0.238 \\
\hline
\end{tabular}

* Dummies of 23 types of categories of instruction and 23 housing types also tested and not significantly different.

students in the control group have on the set of observed characteristics a large resemblance to the students in treatment group. In the remainder of this paper we use the matched sample dataset.

\subsection{Identification strategy}

To estimate the causal effect of residential mobility on school dropout, the dropout status of students with residential mobility $(D=1)$ is compared with the dropout status of students in the matched sample without residential mobility $(D=0)$. As argued before, we only consider people moving within the specific new town as this selected sample reduces the unobserved heterogeneity. Furthermore, we only considered individuals in the control group that have not moved at all between 2001 and 2010, and individuals in the treatment group only if they have not moved again after 2005, and if they did not move in the four years before 2005.

In addition, we believe that the reasons why people move, such as change of jobs, marriage or divorce, addition to the family, or simply because people want a large house (see e.g. Rabe and Taylor, 2010), do not directly influence the drop out decision of youngsters for three reasons: (1) The decision to move is made by the parents and not directly by the students, (2) the characteristics that are related to moving are largely captured by the matching variables, and (3) we know whether people got married or divorced or whether a child was born, so we can take these aspects into account explicitly. The data shows that the latter are indeed highly correlated with residential mobility, however, not with the dropout decision.

The crucial assumption in our simple regression analysis is that observed outcomes for mobile and non-mobile individuals move parallel over time in the absence of residential mobility (Abadie, 2005; Heckman, 1990). The restriction is written as follows:

$$
E\left[y_{0}(1)-y_{0}(0) \mid D=1\right]=E\left[y_{0}(1)-y_{0}(0) \mid D=0\right]
$$

where $D$ represents the mobility of an individual. The potential outcome of a non-mobile individual at $t=0$ is denoted as $y_{0}(0)$, whereas the potential outcome of a mobile individual at $t=1$ is denoted as $y_{1}(1)$. The terms $y_{0}(1)$ and $y_{1}(0)$ are represented in a similar way. Using this assumption, and in line with Heckman et al. (1997), we assume that differences in the dropout rates may only arise due to differences in mobility. Therefore, we matched on a large set of covariates to make sure 
individuals do not differ on these aspects. Furthermore, as stated before, we see that some covariates influence the decision to move, for example divorce or marriage. It is possible that other factors, such as household income, also influence the decision to move. Therefore, we explicitly include divorce, marriage and difference in housing value (as a proxy for income change), as well as average housing value of the neighborhood in our analysis, that we will describe below.

In the empirical estimations, we can identify the effect of residential mobility on early school leaving in three complementary ways. First, we assume that the effect of residential mobility is constant over time and has an immediate influence on early school leaving. This corresponds to estimating a simple first difference model where as a proxy for 'residential mobility' a dummy variable is used:

$$
Y_{i}=\alpha_{0}+\delta_{1} D 1_{i}+\sum \beta_{j} X_{j i}+\gamma_{j} \text { Time }+U_{i}
$$

where $Y_{i}$ is a dummy for the dropout status of individual $i, \alpha_{0}$ is an intercept, $D 1_{i}$ is a dummy for residential mobility (with residential mobility $=1$; without residential mobility $=0), X_{j i}$ is a vector which includes the observable characteristics of the individual $i$, with an element of the set of matched students $j$, Time captures the year fixed effects, and $u_{i}$ is a randomly distributed error term (Wooldridge, 2003). The coefficient of interest is $\delta_{1}$, as this estimates the influence of residential mobility on school dropout. We estimate a panel model in which the mobility dummy equals 1 from the year a student moved onwards. The dropout dummy is set to one from the year a student left school without a higher secondary degree onwards (unless we specifically observe this person being back in the schooling data). All model specifications are estimated by simple ordinary least squares (note that while Probit regressions are less efficient with respect to computation time, they would deliver comparable results).

Second, we can easily relax the assumption behind equation (3) by replacing $D 1$ with a vector corresponding to the number of years since one moved (denoted by D2). This assumes that the years since residential mobility have a linear influence on the dropout behavior of students. This is attractive as, for example, it might take some time to observe the effects of residential mobility. More precisely, we estimate:

$$
Y_{i}=\alpha_{0}+\delta_{1} D 2_{i}+\sum \beta_{j} X_{j i}+\gamma_{j} \text { Time }+U_{i}
$$

where $D 2_{i}$ is an indicator for residential mobility measured by the number of years since the residential mobility (with $2010=1, \ldots, 2005=6$, not moved $=0$ ).

In a third model specification we further relax the assumption behind equation (4) by making the residential mobility indicator non-linear. This is attractive as residential mobility might, for example, initially be beneficial while this effect disappears after some time, or the other way around. The non-linear model adds a squared term for the number of years since one moved to equation (4):

$$
Y_{i}=\alpha_{0}+\delta_{1} D 2_{i}+\delta_{2} D 3_{i}^{2}+\sum \beta_{j} X_{j i}+\gamma_{j} \text { Time }+U_{i}
$$

where $D 2_{i}$ is an indicator for residential mobility (again, the number of years since the residential mobility, with $2010=1, \ldots$, $2005=6$, not moved $=0$, similar to before), $D 3_{i}^{2}$ captures the non-linear influence of the residential mobility. The parameters of interest are $\delta_{1}$ and $\delta_{2}$, which represent the non-linear (quadratic) effect of residential mobility. They allow us to study a potential optimum or minimum.

In a fourth model we test whether the non-linearity might be cubic instead of quadratic, for the same reasons we test the quadratic non-linear specification. The second non-linear model adds a cubic term for the number of years since one moved to equation (5):

$$
Y_{i}=\alpha_{0}+\delta_{1} D 2_{i}+\delta_{2} D 3_{i}^{2}+\delta_{3} D 4_{i}^{3}+\sum \beta_{j} X_{j i}+\gamma_{j} \text { Time }+U_{i}
$$

where $D 2_{i}$ and $D 3_{i}^{2}$ have a similar meaning as in Equation (5). $D 4_{i}^{3}$ captures the cubic non-linear influence of the residential mobility. The parameters of interest are $\delta_{1}, \delta_{2}$ and $\delta_{3}$ which represent the non-linear (quadratic) effect of residential mobility. They allow us to study a potential optimum or minimum.

In each model specification we account for peer effects arising from the school the student attends, and the year. Therefore, we also estimate the models with school and year fixed effects to account for time indifferent variation between schools and years. Besides that, we control for potential serial correlation in the error terms by using robust standard errors and clustering them at the individual level.

Recall that, due to the specific municipality we are considering, not many students with residential mobility change schools. Furthermore, the data shows that the number of students changing schools is comparable across the mover and the non-movers, and the correlation between school changing and residential mobility is almost zero and highly insignificant. $^{7}$ Moreover, as long as the student inflow due to the residential mobility is small, we expect that the new students have little influence on the educational outcome (including dropout behavior) of the other students in the sample. Therefore, we are confident about the stable unit variance assumption behind the model (i.e., the treatment students do not influence the outcome variable of the control students). However, in theory it is still possible that residential moves affect nonmovers by altering

\footnotetext{
${ }^{7}$ Results available upon request from the corresponding author.
} 
neighborhood peer composition and also generating an increase in disruption in the school even in the absence of increasing school turnover (if movers become more disruptive), so we should still be cautious with this assumption.

\section{Results}

The empirical results of estimating equations (3)-(6) are presented in Table 4. As outlined in Section 5, each of the specifications has its own merits and assumptions. Although the underlying data originate from the matched sample, we control in the regressions for a wide range of control variables. In particular, we account for the age, gender, family size, ethnicity (i.e., native Dutch, Antillean, Surinam, Turkish, Moroccan, African, Other non-Western), type of education (i.e., first year, prevocational, vocational, general or pre-university), average housing value of the neighborhood, the type of house the student lives in (i.e., business accommodation, ground floor flat, upstairs flat, gallery flat, row house, semi-detached, quadrant house, maisonnette, other), a dummy for rental house ( $0=$ own the house; $1=$ rents the house), dummies for marriage or divorce within two years before or after the residential mobility, and an indicator variable for upward and downward mobility (i.e., the change in housing value before and after the mobility, which is zero for individuals that have not moved). The housing value is estimated by a specialized government institute and is based on characteristics of the house and neighborhood. We present only regression outcomes with year and school fixed effects. Alternative model specifications, in particular with less control variables, yield similar results and are available upon request.

Note that although the included control variables are largely similar to the variables used in the matching analysis they serve a different purpose in the first difference analysis. Indeed, in the first phase (the matching) the control variables are used to select the look-alike students. In the second phase, they are used to obtain more efficient and consistent estimates by removing remaining heterogeneity among the students. This approach is in line with, among others, Heckman and Hotz (1989).

The influence of residential mobility on early school leaving for the four different model assumptions is presented in Table 4. Model 1 presents the effect of a simple measure of residential mobility, as is used in most literature described earlier in this paper. The results suggest a positive but significant effect of residential mobility on school dropout. In other words, compared with well-comparable students who did not move, students with residential mobility drop out of school more frequently, and this effect is significantly different from zero. The positive sign of the residential mobility effect on school dropout when only accounting for the fact that someone has moved (without taking into account when someone moved) is in line with the findings of South et al. (2007), although it should be noted that South et al. consider residential and school move simultaneously.

The panel data structure allows us to go beyond a discrete indicator of residential mobility. We can analyze the linear effect of time since someone has moved. The outcomes are presented in Model 2 of Table 4. It indicates a positive, but insignificant coefficient of the number of years since moving. Students with residential mobility face a higher risk for early school leaving, although not significantly different from zero.

Finally, we have argued before that the influence of residential mobility might not be linear over time. We capture this first of all by including a quadratic term of years since the residential mobility. This further allows us to study the existence of a potential optimum. The results are presented in Model 3 of Table 4. This reveals that the coefficient of $\delta_{1}$ has a positive and significant sign and that the coefficient of the squared effect of years since moving (i.e., $\delta_{2}$ ) has a negative and significant sign. This implies that the effect of the number of years since moving is upward sloping in the first couple of years, but turns into an downward slope when the time since moving increases. Given the significant results of $\left(\delta_{2}\right)$ we can conclude that the number of years since residential mobility has a non-linear influence on early school leaving. Next, we check whether there might be a cubic relation between years of moving and dropout. Model 4 of Table 4 shows the results of the cubic model. Here we see that $\delta_{1}$ and $\delta_{2}$, have similar signs and significance as in Model 3, but that the cubic term is also highly significant, and positive. Indicating a cubic effect of moving on dropout, where the effect is positive in the first years, negative in the following years, but turns positive again in the longer run. ${ }^{8}$

Some interesting results across the three model specifications can be observed. We see that the underlying regressions (see Appendix) reveal that the main outcomes are not driven by the age of the student, nor by time fixed effects. Even if we control for time fixed effects which arise from, e.g., an increased awareness for a higher secondary degree or from policy interventions to reduce early school leaving, the coefficients for both $\delta_{1}$ and $\delta_{2}$ prevail. However, we do see that the age of the student significantly influences the dropout decision. Third, the results of the full regressions suggest that the correlation between the changes in housing value and early school leaving is low. The indicator variable is zero and highly insignificant in all specifications. In the additional analyzes we focus on separating upward mobility from downward mobility. A change is considered downward mobility if there is a decrease in housing value, whereas a change is considered upward mobility if there is an increase in housing value.

Besides estimating the average trend effects, it is interesting to explore the effects of every year separately. This is estimated by including six dummy variables representing the time since the move (this contrasts the earlier linear and non-linear terms which are continuous variables). ${ }^{9}$ Fig. 2 graphically presents the estimated coefficients and their $95 \%$

\footnotetext{
${ }^{8}$ Note that we also tested the next model which included a quadratric term, but that made all coefficients of interests insignificant, and shows that this is not the correct function form for this effect.

9 Detailed results are available upon request from the corresponding author.
} 
Table 4

The influence of residential mobility on school dropout.

\begin{tabular}{|c|c|c|c|c|}
\hline $\begin{array}{l}\text { Dependent variable: school dropout } \\
\text { Variable of interest }\end{array}$ & $\begin{array}{l}\text { Model } 1 \\
\text { Dummy } \\
\text { variable } \\
\text { (Eq. (3)) }\end{array}$ & $\begin{array}{l}\text { Model } 2 \\
\text { Indicator } \\
\text { variable } \\
\text { (Eq. (4)) }\end{array}$ & $\begin{array}{l}\text { Model } 3 \\
\text { Squared indicator variable (Eq. (5)) }\end{array}$ & $\begin{array}{l}\text { Model } 4 \\
\text { Cubic indicator variable (Eq. (6)) }\end{array}$ \\
\hline Underlying assumption & Discrete effect & Linear effect & Non-linear effect & Non-linear effect \\
\hline Estimated effect residential mobility & 0.023 & 0.003 & 0.019 & 0.058 \\
\hline$t$-Statistic & 2.050 & 0.940 & 2.260 & 2.930 \\
\hline Estimated effect squared & & & -0.004 & -0.025 \\
\hline$t$-Statistic & & & -2.390 & -2.920 \\
\hline Estimated effect cubic & & & & 0.003 \\
\hline$t$-Statistic & & & & 2.840 \\
\hline Covariates $\left(X_{j i}\right)$ & \multicolumn{4}{|c|}{ Individual, educational, housing and neighborhood characteristics } \\
\hline Fixed effects & & & ar and school level & \\
\hline Observations $(n)$ & 9886 & 9886 & 9886 & 9886 \\
\hline
\end{tabular}

Robust standard errors clustered at the individual level.

Note that Model 1 measures residential mobility with a dummy variable (with residential mobility = 1 ; without residential mobility = 0 ); Model 2 uses an indicator for residential mobility measured by the number of years since the residential mobility ( with $2010=1, \ldots, 2005=6$, not moved $=0$ ); Model 3 adds a quadratic term to Model 2, and Model 4 adds a cubic term to Model 3.

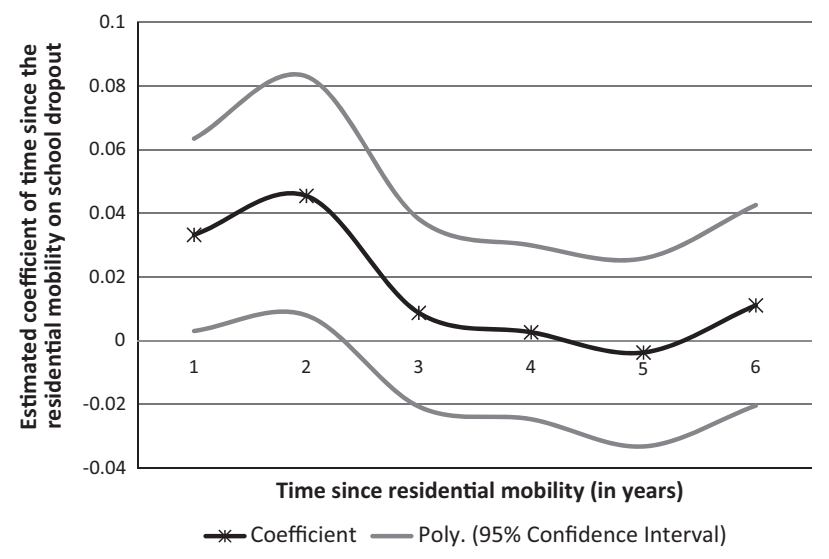

Fig. 2. The estimated influence of the number of years since residential mobility on school dropout.

confidence intervals. The figure clearly shows the upward trend in the first two years, the downward trend in years three to five after moving, and again the upward effect from year 6 on. It further reveals that the effect of residential mobility is positive in the first, second, third fourth and sixth year after moving (of which the effect in years 1 and 2 is significant at the $1 \%$ level, and the effect in year six at the 10 percent level). This implies that residential mobility (significantly) decreases dropout in the short and long run, but not in the medium run. Fig. 2 further suggests that the effect in the fifth year after moving is negative. Our (short run) findings are in line with earlier literature (e.g. Gasper et al., 2011; South et al., 2007; Swanson and Schneider, 1999).

\subsection{The potential underlying mechanisms}

Our main finding that school dropout significantly increases in the first two years, and again after six years, could be due to several reasons.

First, there is the influence of changing the neighborhood which results in new peers (see e.g. Feijten and Van Ham, 2009; Gibbons et al., 2013, although Gibbons et al. focus their study on residential stayers).

Second, our evidence suggests that moving to a different neighborhood might have different effects in the short and long than in the medium run. In the short run and long run we see a positive effect (so increased dropout) whereas in the medium run we see a negative effect (less dropout, although not significant). There most likely is a direct short term effect of the shock of moving, where a child has to adjust to so many changes that it increases risk of dropout. This in line with earlier literature. However, this does not explain why the effect only shows again after six years, and not after, for example, five years. A potential explanation for the fact that the negative effect shows again after six years could be due to the decreasing housing prices since 2008. All residential movement in our data set took place in 2005, long before the housing crisis. After 
Table 5

The influence of residential mobility on school dropout - separately for moving up and moving down.

\begin{tabular}{|c|c|c|c|c|c|c|c|c|}
\hline \multirow{3}{*}{$\begin{array}{l}\text { Dependent variable: } \\
\text { school dropout } \\
\text { Variable of interest }\end{array}$} & \multicolumn{4}{|l|}{ Moving up } & \multicolumn{4}{|l|}{ Moving down } \\
\hline & Model 1 & Model 2 & Model 3 & Model 4 & Model 1 & Model 2 & Model 3 & Model 4 \\
\hline & $\begin{array}{l}\text { Dummy variable } \\
\text { (Eq. (3)) }\end{array}$ & $\begin{array}{l}\text { Indicator } \\
\text { variable (Eq. (4)) }\end{array}$ & $\begin{array}{l}\text { Squared indicator } \\
\text { variable (Eq. (5)) }\end{array}$ & $\begin{array}{l}\text { Cubic indicator } \\
\text { variable (Eq. (6)) }\end{array}$ & $\begin{array}{l}\text { Dummy variable } \\
\text { (Eq. (3)) }\end{array}$ & $\begin{array}{l}\text { Indicator } \\
\text { variable (Eq. (4)) }\end{array}$ & $\begin{array}{l}\text { Squared indicator } \\
\text { variable (Eq. (5)) }\end{array}$ & $\begin{array}{l}\text { Cubic indicator } \\
\text { variable (Eq. (6)) }\end{array}$ \\
\hline Underlying assumption & Discrete effect & Linear effect & Non-linear effect & Non-linear effect & Discrete effect & Linear effect & Non-linear effect & Non-linear effect \\
\hline $\begin{array}{l}\text { Estimated effect } \\
\text { residential mobility }\end{array}$ & 0.021 & 0.003 & 0.017 & 0.060 & 0.023 & 0.003 & 0.018 & 0.066 \\
\hline$t$-Statistic & 1.780 & 0.980 & 1.980 & 2.630 & 1.960 & 1.100 & 2.140 & 2.920 \\
\hline $\begin{array}{l}\text { Estimated effect } \\
\text { squared }\end{array}$ & & & -0.003 & -0.026 & & & -0.003 & -0.029 \\
\hline$t$-Statistic & & & -2.030 & -2.640 & & & -2.150 & -2.920 \\
\hline Estimated effect cubic & & & & 0.003 & & & & 0.003 \\
\hline t-Statistic & & & & 2.600 & & & & 2.880 \\
\hline Covariates $\left(X_{j i}\right)$ & \multirow{2}{*}{\multicolumn{8}{|c|}{$\begin{array}{l}\text { Individual, educational, housing and neighborhood characteristics } \\
\text { Year and school level }\end{array}$}} \\
\hline Fixed effects & & & & & & & & \\
\hline Observations ( $n$ ) & 9212 & 9212 & 9212 & 9212 & 8843 & 8843 & 8843 & 8843 \\
\hline
\end{tabular}

Robust standard errors clustered at the individual level.

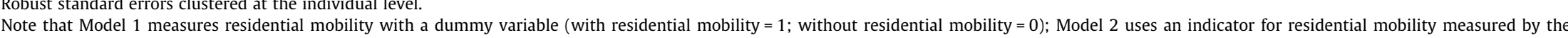
number of years since the residential mobility (with $2010=1, \ldots, 2005=6$, not moved =0); Model 3 adds a quadratic term to Model 2, and Model 4 adds a cubic term to Model 3. 
2008 housing prices decreased each year, which could have influenced parents' labor market outcomes (Ham van and Feijten, 2008) and thereby may have influenced the children as well.

As a third mechanism, school quality could have decreased. This can be due to residential mobility which increases in rigorous educational environments independent of tract location, thereby shutting out students. The students who moved may be at a competitive disadvantage relative to their new peers who have always attended those schools. This combined with the residential mobility could lead to significant effects (Bowles and Gintis, 2002; Lee and Loeb, 1995; Lucas, 2007). Nevertheless, we do not observe a decrease in school quality since (1) most students that move within the municipality do not change schools, and (2) evidence from the Dutch Education Inspectorate indicates that there is no decrease in education quality or school quality in this municipality over the relevant time period. Furthermore, our analysis shows that the chance of changing schools is completely unrelated to residential mobility. Therefore, changes in school composition, and thus school quality, seem unrelated to the residential mobility and therefore the effects that we find cannot be explained by changes in school quality.

As a final explanation of the interesting time pattern in the results, and especially the positive effect again after six years, we point to the age of the student at which the family moves. The average age at which students are moving to a new neighborhood is 14 years old. While earlier literature (e.g., Cabus and De Witte, 2011) indicate that the age of 14 is not a critical age to drop out of school, it is some years later. If students reach the age of 17 , the probability of leaving school without a higher secondary degree increases significantly. While most of this 'age effect' is captured by the 'age' variable in the matching analysis and the regression specifications, it might still not fully capture the disruption of the move at a critical age of the student, and thereby explain the significant effect after six year.

\subsection{Robustness analysis}

To test the robustness of the results, we run various alternative specifications. First, we analyze the results separately for upward and downward mobility. Table 5 shows the empirical results of equations (3)-(6) for upward and downward mobility separate. Note that downward mobility is highly and significantly correlated to divorce of parents, right before the decision to move. However, marriage right before the decision to move is not correlated with upward mobility (nor with downward mobility, for that matter). The results show that the conclusions based on Table 4 remain, regardless of whether the residential move is upward or downward. Additional analysis show that different definitions of upward and downward mobility, for example by creating quintiles of the change in housing value of the old and the new house, also do not lead to different results. All the coefficients of interest remain highly significant, whether we define upward and downward mobility as at least a change of one, two, three or four quintiles. These analyzes are available upon request.

This suggests that a residential change on its own already has significant effects on early school leaving, without there being need for large differences in economic circumstances or large differences in the neighborhoods they came from and move into. The finding that there is no difference in effect for students that move up or move down is in line with the study by Sharkley (2012). Furthermore, the finding of Sharkley and Elwert (2011), that a child's schooling outcomes are largely dependent on the neighborhood where the parents grew up, could also explain why residential mobility in the short and medium run influences dropout similarly, regardless of where you move.

As a second robustness test we distinguish three types of schooling level: (1) Primary, special and prevocational secondary education, (2) general upper and pre academic secondary education, and (3) vocational, higher professional and adult education. From the results in Table 6 we conclude that the estimates are largely driven by movers and dropouts in the third group, namely vocational, higher professional and adult education (which obviously makes sense given the type of education and age of these students). All the coefficients are significant at the $10 \%$ level for the second group, the general upper and pre

Table 6

The influence of residential mobility on school dropout - separately for three groups of educational levels.

\begin{tabular}{|c|c|c|c|}
\hline $\begin{array}{l}\text { Dependent variable: } \\
\text { school dropout } \\
\text { Variable of interest } \\
\text { Underlying assumption }\end{array}$ & $\begin{array}{l}\text { Primary, special and prevocational } \\
\text { secondary education } \\
\text { Cubic indicator variable (Eq. (6)) } \\
\text { Non-linear effect }\end{array}$ & $\begin{array}{l}\text { General upper and pre academic } \\
\text { secondary education } \\
\text { Cubic indicator variable (Eq. (6)) } \\
\text { Non-linear effect }\end{array}$ & $\begin{array}{l}\text { Vocational, higher professional and } \\
\text { adult education } \\
\text { Cubic indicator variable (Eq. (6)) } \\
\text { Non-linear effect }\end{array}$ \\
\hline $\begin{array}{l}\text { Estimated effect } \\
\text { residential mobility }\end{array}$ & 0.002 & 0.084 & 0.161 \\
\hline$t$-Statistic & 0.130 & 1.710 & 2.420 \\
\hline Estimated effect squared & -0.003 & -0.034 & -0.068 \\
\hline$t$-Statistic & -0.520 & -1.660 & -2.310 \\
\hline Estimated effect cubic & 0.001 & & \\
\hline$t$-Statistic & 0.690 & 1.670 & 2.260 \\
\hline Covariates $\left(X_{j i}\right)$ & \multirow{2}{*}{\multicolumn{3}{|c|}{$\begin{array}{l}\text { Individual, educational, housing and neighborhood characteristics } \\
\text { Year and school level }\end{array}$}} \\
\hline Fixed effects & & & \\
\hline Observations ( $n$ ) & 5355 & 2133 & 2398 \\
\hline
\end{tabular}

Robust standard errors clustered at the individual level.

Note that this table uses the regression of Eq. (6) (Model 4) and thus assumes a non-linear effect of residential mobility on early school leaving. The results of models 1-3 are available upon request. 
Table 7

Robustness analysis on different subsamples.

\begin{tabular}{|c|c|c|c|c|c|}
\hline \multirow[t]{2}{*}{ Dependent var = school dropout } & \multirow{2}{*}{$\begin{array}{l}\text { Subsample } \\
\text { Dropout age until } 23\end{array}$} & \multirow{2}{*}{$\begin{array}{l}\text { Subsample } \\
\text { Only students for } 6 \text { years in data }\end{array}$} & \multirow{2}{*}{$\begin{array}{l}\text { Original sample } \\
\text { Unbalanced data }\end{array}$} & \multicolumn{2}{|c|}{$\begin{array}{l}2 \text { Subsamples by } \\
\text { ethnicity students }\end{array}$} \\
\hline & & & & Dutch & Other \\
\hline Estimated effect residential mobility & 0.040 & 0.047 & 0.048 & 0.077 & 0.031 \\
\hline$t$-Statistic & 1.890 & 2.180 & 3.230 & 3.270 & 0.860 \\
\hline Estimated effect squared & -0.015 & -0.018 & -0.019 & -0.030 & -0.020 \\
\hline$t$-Statistic & -1.590 & -2.190 & -2.970 & -3.030 & -1.290 \\
\hline Estimated effect cubic & 0.001 & 0.002 & 0.002 & 0.003 & 0.003 \\
\hline$t$-Statistic & 1.380 & 2.120 & 2.710 & 2.720 & 1.580 \\
\hline Covariates $\left(X_{j i}\right)$ & \multicolumn{5}{|c|}{$\begin{array}{l}\text { Individual, educational, housing and neighborhood characteristics } \\
\text { Year and school level }\end{array}$} \\
\hline Observations ( $n$ ) & 10,414 & 5366 & 8278 & 5935 & 3951 \\
\hline
\end{tabular}

Robust standard errors clustered at the individual level

Note that this table uses the regression of Equation (6) (Model 4) and thus assumes a non-linear effect of residential mobility on early school leaving. The results of models $1-3$ are available upon request.

academic secondary students, and none of the coefficients is significant in the analysis of students in primary, special and prevocational secondary education.

Third, we increased the sample to include students until the dropout age of 23 (which is the official dropout age, but has potential problems with registration, which is why we did not use this age range for the analysis in the first place (see Cabus and De Witte, 2011)). The results of this increased sample in Table 7 indicate similar effects as before, both in magnitude and in significance.

Fourth, we exploit the panel structure in the data in a different way. We focus only on students which we observe for 6 years in the data, i.e. between 2005 and 2010. This way we do not have to create duplicates. This comes at a cost of losing many observations. Therefore, as a fifth robustness analysis, we also check the results if we simply use the original sample without creating duplicates or removing observations. Both analyzes present very similar results as are presented in Table 4, both in magnitude and in significance.

Finally, we limit the sample to only migrant or native students. This makes an interesting robustness analysis as it avoids any effects arising from the ethnicity of the student. All robustness analyzes show similar results to the results presented for Model 3 in Table 4.

We can conclude that the results are robust against alternative specifications and samples. This gives confidence to our empirical findings.

\section{Conclusion and discussion}

The influence of residential mobility on education outcomes has attracted only limited attention in previous literature. This paper studied the effect of residential mobility on school dropout in a large new town in the Netherlands (more precisely, the seventh largest city in the Netherlands). As new towns are specially constructed for low and middle income groups and as they are characterized with continuous attempts to improve the living circumstances in the neighborhoods (e.g., by renewing neighborhoods, or by constructing new neighborhoods), one can observe significant migration patterns within new towns.

Evidence on the relationship between residential mobility and early school leaving is obtained in two steps. In a first step, we used a matching procedure to construct for every treated student a look-a-like control student. By matching on a wide set of observed characteristics, we argued that the control students are similar to the treated students on also the unobserved characteristics. Also, we argue that the reasons why people move can either be incorporated in our analysis or do not influence a students' decision to drop out. In a second step, we used a first difference estimator to examine the effect of residential mobility on school dropout.

The results show that, controlled for individual, family, educational, neighborhood and housing characteristics, as well as for school and year fixed effects, residential mobility increases the chances of dropping out in the first few years after moving, but this changes to a decreasing risk of dropping out after a couple of years, and back to an increasing risk from the 6th year on. This implies a short and long term negative effect of residential mobility, but an insignificant medium term effect. We find the same results if we separate upward (i.e., moving to a more valuable house) from downward (i.e., moving to a less valuable house) mobility. We also find that the results are largely driven by movers and dropouts among vocational students. The increase in dropout rates in the first two years is intuitive because of the direct shock, and the increase again after six years might be explained by neighborhood changes, decreasing housing values, or decreasing school quality. The negative effects in the short and long run correspond to findings of South et al. (2007), Gasper et al. (2011).

The results should be interpreted with sufficient caution. While we control for various sources of observed heterogeneity (e.g., due to divorce, marriage, income change, family composition), there might be some unobserved heterogeneity left (e.g., due to unobserved income shifts, motivation and aspiration of individuals). As a second source of concern, students with 
Table A1

Full estimation results Table 4 for Models 1-4.

\begin{tabular}{|c|c|c|c|c|c|c|c|c|}
\hline & Model 1 & & Model 2 & & Model 3 & & Model 4 & \\
\hline Number of obs. $=$ & 9886 & & 9886 & & 9886 & & 9886 & \\
\hline$R$-squared $=$ & 0.267 & & 0.266 & & 0.267 & & 0.268 & \\
\hline Root MSE= & 0.233 & & 0.234 & & 0.234 & & 0.233 & \\
\hline Dropout & Coef. & $t$ & Coef. & $t$ & Coef. & $t$ & Coef. & $t$ \\
\hline Moved ( 1 = yes, since moving year)/years since moved & 0.023 & 2.050 & 0.003 & 0.940 & 0.019 & 2.260 & 0.058 & 2.930 \\
\hline Years since moved squared & & & & & -0.004 & -2.390 & -0.025 & -2.920 \\
\hline Years since moved squared & & & & & & & 0.003 & 2.840 \\
\hline Age 7 & 0.017 & 2.600 & 0.017 & 2.650 & 0.017 & 2.660 & 0.016 & 2.480 \\
\hline Age 8 & 0.031 & 3.770 & 0.032 & 3.880 & 0.031 & 3.820 & 0.029 & 3.490 \\
\hline Age 9 & 0.044 & 5.060 & 0.045 & 5.200 & 0.044 & 5.060 & 0.042 & 4.650 \\
\hline Age 10 & 0.060 & 5.850 & 0.061 & 6.000 & 0.060 & 5.780 & 0.058 & 5.470 \\
\hline Age 11 & 0.075 & 6.670 & 0.076 & 6.840 & 0.074 & 6.550 & 0.073 & 6.380 \\
\hline Age 12 & 0.095 & 6.910 & 0.097 & 7.100 & 0.093 & 6.750 & 0.091 & 6.540 \\
\hline Age 13 & 0.119 & 7.430 & 0.122 & 7.640 & 0.116 & 7.210 & 0.113 & 6.900 \\
\hline Age 14 & 0.144 & 7.890 & 0.147 & 8.110 & 0.141 & 7.710 & 0.136 & 7.350 \\
\hline Age 15 & 0.160 & 8.040 & 0.164 & 8.220 & 0.157 & 7.880 & 0.151 & 7.500 \\
\hline Age 16 & 0.176 & 8.030 & 0.180 & 8.230 & 0.173 & 7.890 & 0.166 & 7.510 \\
\hline Age 17 & 0.187 & 7.140 & 0.191 & 7.330 & 0.184 & 7.020 & 0.176 & 6.660 \\
\hline Age 18 & 0.240 & 7.680 & 0.246 & 7.870 & 0.237 & 7.590 & 0.228 & 7.230 \\
\hline Age 19 & 0.267 & 7.500 & 0.273 & 7.690 & 0.264 & 7.440 & 0.254 & 7.100 \\
\hline Age 20 & 0.321 & 7.510 & 0.327 & 7.680 & 0.317 & 7.500 & 0.305 & 7.150 \\
\hline Age 21 & 0.334 & 7.110 & 0.340 & 7.270 & 0.330 & 7.100 & 0.317 & 6.760 \\
\hline Age 22 & 0.388 & 7.450 & 0.395 & 7.570 & 0.384 & 7.420 & 0.371 & 7.140 \\
\hline Age 23 & 0.480 & 8.180 & 0.486 & 8.260 & 0.476 & 8.100 & 0.463 & 7.900 \\
\hline Gender ( 1 = female) & -0.004 & -0.390 & -0.004 & -0.360 & -0.004 & -0.370 & -0.005 & -0.410 \\
\hline Family size & -0.006 & -1.130 & -0.006 & -1.140 & -0.006 & -1.100 & -0.006 & -1.130 \\
\hline Special education & 0.227 & 3.290 & 0.224 & 3.170 & 0.216 & 3.130 & 0.213 & 3.190 \\
\hline Practical education & 0.399 & 4.670 & 0.386 & 4.440 & 0.379 & 4.440 & 0.387 & 4.650 \\
\hline Years 1 and 2 secondary education & 0.255 & 2.960 & 0.256 & 2.970 & (omitted) & 0.000 & 0.244 & 2.850 \\
\hline VMBO & 0.285 & 5.910 & 0.287 & 5.910 & 0.268 & 5.630 & (omitted) & 0.000 \\
\hline HAVO & 0.310 & 6.030 & 0.312 & 6.030 & 0.295 & 5.840 & 0.300 & 5.910 \\
\hline VWO & (omitted) & 0.000 & (omitted) & 0.000 & (omitted) & 0.000 & (omitted) & 0.000 \\
\hline MBO & -0.015 & -0.850 & -0.014 & -0.800 & -0.015 & -0.830 & -0.015 & -0.870 \\
\hline HBO & 0.241 & 2.310 & 0.242 & 2.310 & 0.225 & 2.170 & 0.230 & 2.230 \\
\hline Adult education & 0.308 & 3.200 & 0.311 & 3.240 & 0.295 & 3.080 & 0.295 & 3.080 \\
\hline Antillean & -0.068 & -2.880 & -0.068 & -2.890 & -0.069 & -2.900 & -0.068 & -2.890 \\
\hline Surinam & -0.002 & -0.120 & -0.002 & -0.110 & -0.002 & -0.110 & -0.002 & -0.140 \\
\hline Turkish & 0.125 & 2.130 & 0.125 & 2.130 & 0.125 & 2.130 & 0.125 & 2.130 \\
\hline Moroccan & -0.050 & -2.140 & -0.050 & -2.140 & -0.050 & -2.150 & -0.049 & -2.110 \\
\hline African & -0.051 & -1.330 & -0.050 & -1.300 & -0.051 & -1.300 & -0.054 & -1.390 \\
\hline Other non-Western & -0.009 & -0.310 & -0.008 & -0.280 & -0.009 & -0.310 & -0.009 & -0.320 \\
\hline Other Western & 0.013 & 0.550 & 0.014 & 0.560 & 0.013 & 0.550 & 0.013 & 0.540 \\
\hline Rental house dummy & 0.008 & 0.500 & 0.007 & 0.470 & 0.007 & 0.480 & 0.007 & 0.490 \\
\hline Average housing value in the neighborhood & 0.000 & -1.360 & 0.000 & -1.430 & 0.000 & -1.370 & 0.000 & -1.340 \\
\hline Housing type 3 : business accommodation & -0.080 & -1.770 & -0.082 & -1.760 & -0.079 & -1.740 & -0.078 & -1.720 \\
\hline Housing type 4 : ground floor flat & 0.439 & 4.480 & 0.449 & 4.580 & 0.436 & 4.420 & 0.426 & 4.330 \\
\hline Housing type 5: upstairs flat & -0.134 & -0.920 & -0.140 & -0.950 & -0.138 & -0.940 & -0.134 & -0.920 \\
\hline Housing type 7 : gallery flat & 0.080 & 1.360 & 0.082 & 1.390 & 0.079 & 1.350 & 0.077 & 1.310 \\
\hline Housing type 8 : row house & 0.053 & 1.480 & 0.054 & 1.470 & 0.054 & 1.480 & 0.053 & 1.470 \\
\hline Housing type 9: semi-detached & 0.029 & 0.950 & 0.029 & 0.960 & 0.029 & 0.940 & 0.028 & 0.930 \\
\hline Housing type 10 : quadrant house & 0.141 & 0.830 & 0.137 & 0.800 & 0.138 & 0.820 & 0.138 & 0.830 \\
\hline Housing type 11 : maisonnette & 0.005 & 0.120 & 0.005 & 0.140 & 0.005 & 0.120 & 0.005 & 0.130 \\
\hline Housing type 12 : other & 0.734 & 13.670 & 0.735 & 13.390 & 0.756 & 14.020 & 0.746 & 13.820 \\
\hline Housing type 14 : flat other & 0.028 & 0.390 & 0.027 & 0.380 & 0.028 & 0.400 & 0.027 & 0.390 \\
\hline Housing type 17: porch flat & -0.003 & -0.100 & -0.004 & -0.140 & -0.004 & -0.120 & -0.004 & -0.120 \\
\hline Housing type 18 : row house (corner) & 0.037 & 1.400 & 0.037 & 1.410 & 0.037 & 1.400 & 0.036 & 1.380 \\
\hline Housing type 20: row house (middle) & 0.010 & 0.500 & 0.009 & 0.460 & 0.010 & 0.480 & 0.010 & 0.490 \\
\hline Housing type 21 : temporary & -0.105 & -3.350 & -0.098 & -3.160 & -0.107 & -3.360 & -0.097 & -3.090 \\
\hline Housing type 22 : detached & 0.011 & 0.380 & 0.012 & 0.400 & 0.011 & 0.380 & 0.011 & 0.360 \\
\hline Year 2006 & -0.021 & -5.900 & -0.022 & -5.850 & -0.025 & -6.060 & -0.022 & -5.460 \\
\hline Year 2007 & -0.046 & -9.100 & -0.048 & -8.620 & -0.050 & -8.650 & -0.040 & -6.550 \\
\hline Year 2008 & -0.070 & -10.540 & -0.073 & -9.950 & -0.072 & -9.920 & -0.057 & -6.790 \\
\hline Year 2009 & -0.096 & -10.900 & -0.099 & -10.340 & -0.094 & -9.950 & -0.082 & -7.770 \\
\hline Year 2010 & -0.123 & -10.420 & -0.129 & -9.980 & -0.116 & -9.360 & -0.112 & -8.830 \\
\hline Difference in housing value & 0.000 & 1.400 & 0.000 & 1.620 & 0.000 & 1.480 & 0.000 & 1.260 \\
\hline Married right before or since moving & -0.050 & -2.290 & -0.047 & -2.200 & -0.049 & -2.260 & -0.050 & -2.320 \\
\hline Divorced right before or since moving & 0.016 & 1.050 & 0.020 & 1.330 & 0.017 & 1.120 & 0.015 & 1.010 \\
\hline Constant & -0.371 & & -0.373 & -4.440 & -0.352 & -4.270 & -0.357 & -4.250 \\
\hline
\end{tabular}

Dummies for type of education and school, robust standard errors clustered at the individual level. 
residential mobility might have different experiences before move than students that do not move. Although we extensively argued that our estimate captures the causal effect of residential mobility on school dropout, this unobserved heterogeneity might still result in endogeneity issues. Nevertheless, as the multiple robustness tests (on different subsamples and with different covariates) point to similar outcomes, we remain very confident in the estimates. In other words, the various subsamples, the additional control variables and the fixed effects in the regression analysis control for the salient differences in work, family, and schooling experiences of movers versus non-movers, such that we do not mistakenly conclude an effect of moving when it is in fact an effect of, for example, income differences. And although some of these coefficients are significant, the moving effect is still present after taking all this into account. Finally, we lack data on students who moved to another city, which can introduce some sample selection bias. Given that this group of students is relatively small, we do not expect that our results are sensitive to this source of bias.

This paper provides various avenues for further research. First, the concept of residential mobility can be seen as a part of social mobility, and it could be interesting to study other sources of social mobility (e.g. occupational, financial or intellectual mobility). Second, one can consider alternative outcome variables as education level or test scores. While those outcome variables are more prone to measurement errors, they are clearly relevant for policy making. Third, one can test the external validity of this paper by examining whether its results hold for alternative settings. This should answer the question whether our findings hold for towns with 'normal' internal migration percentages (instead of new towns), or whether the result would also hold for simultaneous school and residential mobility of students.

Our findings have some clear policy relevance. As we argue the relationship between residential mobility and education outcomes, we show the importance of a holistic approach towards education. Our results suggest that the social perspectives are important for education outcomes. Also the living environment matters for education. Moreover, the results suggest the importance of the housing market. The current difficulties on the housing market can have their impact on the educational performance of students. This paper shows that an adequate policy towards the housing market will have its effects on other sectors as well.

\title{
Appendix A. Detailed estimation results
}

\author{
See Table A1.
}

\section{References}

Abadie, A., 2005. Semiparametric difference-in-difference estimators. Rev. Econ. Stud. 72, 1-19.

Amato, P.R., 2000. The consequences of divorce for adults and children. J. Marriage Family 62 (1269-1287).

Astone, M., McLanahan, S., 1994. Family structure, residential mobility and school dropout: a research note. Demography 31 (4), 575-584.

Bartley, M., Plewis, I., 2007. Increasing social mobility: an effective policy to reduce health inequalities. J. R. Stat. Soc. 170 (Part 2), $469-481$.

Black, S.E., Devereux, P.J., Salvanes, K.G., 2010. Under pressure? The effect of peers on outcomes of young adults. NBER Working Paper Seires16004.

Boschma, R.A., Fritsch, M., 2009. Creative class and regional growth: empirical evidence from seven European countries. Econ. Geograpy 85 (4), $391-423$.

Bowles, S., Gintis, H., 2002. The inheritance of inequality. J. Econ. Perspect. 16 (3), 3-30.

Brown, L.A., Moore, E.G., 1970. The intra-urban migration process: a perspective. Geografiska Annaler B 52 (1), 1-13.

Burt, C., 2011. Intelligence and social mobility. J. Stat. Psych. 14 (1), 3-24.

Cabus, S., De Witte, K., 2011. Does school time matter? - On the impact of compulsory education age on school dropout. Econom. Educ. Rev. 30, $1384-1398$. Cameron, A.C., Trivedi, P.K., 2005. Microeconometrics - Methods and Applications. Cambridge University Press.

CBS, 2012. Statline Numbers on Internal Migration in Municipalities, 2005-2010.

Checci, D., Flabbi, L., 2007. Intergenerational mobility and schooling decisions in Germany and Italy: the impact of secondary school tracks. IZA Discussion Paper No. 2876.

Chen, J., 2013. Housing tenure, residential mobility and adolescents' education achievement: evidence from Sweden. Ann. Reg. Sci. 50 (1), $275-294$.

Clark, W.A.V., Dieleman, F.M., 1996. Households and Housing: Choice and Outcomes in the Housing Market. CUPR Press, Rutgers University, New Jersey.

Clark, C., Ledwith, V., 2006. Mobility, housing stress and neighbourhood contexts: evidence from Los Angeles. Environ. Plann. A 38, $1077-1093$.

Clark, W.A.V., Deurloo, M., Dieleman, F.M., 2006. Residential mobility and neighbourhood outcomes. Housing Stud. 21 (3), 323-342.

Clark, C., Scadifi, B., Swinton, J.R., 2012. Do peers influence achievement in high school economics? Evidence from Georgia's economics end course test. J. Econ. Educ. 42 (1), 3-18.

Coleman, J.S., 1988. Social capital in the creation of human capital. Am. J. Sociol. 94 (Suppl), S95-S120.

Crane, J., 1991. The epidemic theory of ghettos and neighborhood effects on dropping out and teenage childbearing. Am. J. Sociol. 96 (5), 1226-1259.

Crowder, K.D., South, S.J., 2011. Spatial and temporal dimensions of neighborhood effects on high school graduation. Soc. Sci. Res. 40, 87-106.

De Witte, K., Van Klaveren, C., Smets, A., 2015. Selective migration in new towns: influence on regional accountability in early school leaving. Regional Studies (accepted for publication).

De Witte, K., Cabus, S., 2013. Dropout prevention measures in the Netherlands, an explorative evaluation. Educational Rev. 65 (2), $155-176$.

De Witte, K., Rogge, N., 2012. Dropout from secondary education: all's well that begins well. Eur. J. Educ. 47 (4), 1-20.

DeWit, D.J., 1998. Frequent childhood geographic relocation: its impact on drug use initiation and the development of alcohol and other drug-related problems among adolescents and young adults. Addict. Behav. 23 (5), 623-634.

Dieleman, F.M., 2001. Modelling residential mobility; a review of recent trends in research. J. Housing Built Environ. 16, 249-265.

Education Inspectorate, 2010. De staat van het onderwijs - Onderwijsverslag 08/09. Utrecht: Inspectie van het Onderwijs.

Ellen, I., 2000. Sharing America's Neighborhoods Cambridge. Harvard University Press.

Feijten, P., Van Ham, M., 2009. Neighbourhood change. Reason to leave? Urban Studies 46 (10), 2103-2122.

Galster, G., Hedman, L., 2012. Neighborhoods, neighborhood effects, and residential mobility: a holistic view and future directions.

Galster, G., Andersson, R., Musterd, S., Kauppinen, T., 2008. Does neighborhood income mix affect earnings of adults? New evidence from Sweden. J. Urban Econom. 63 (3), 858-870.

Galster, G., Andersson, R., Musterd, S., 2010. Who is affected by neighborhood income mix? Gender, age, family, employment and income differences. Urban Stud. 47 (14), 2915-2944.

Gasper, J., Deluca, S., Estacion, A., 2010. Coming and going: explaining the effects of residential and school mobility on adolescent delinquency. Soc. Sci. Res. 39, 459-476. 
Gasper, J., DeLuca, S., Estacion, A., 2011. Switching schools: reconsidering the relationship between school mobility and dropout. Working Paper.

Gibbons, S., Silva, O., Weinhardt, F., 2013. Everybody needs good neighbours? Evidence from students' outcomes in England. Econ. J. 123 (571), $831-874$.

Hagan, J., MacMillan, R., Wheaton, B., 1996. New kid in town: social capital and the life course effects of family migration on children. Am. Sociol. Rev. 61, 368-385.

Hall, P., Tewder-Johnes, M., 2010. Urban and regional planning: Routledge.

Ham van, M., Clark, C., 2009. Neighbourhood mobility in context: household moves and changing neighbourhoods in the Netherlands. Environ. Plann. A 41, $1442-1459$.

Ham van, M., Feijten, P., 2008. Who wants to leave the neighbourhood? The effect of being different from the neighbourhood population on wishes to move. Environ. Plann. A 40, 1151-1170.

Hango, D.W., 2003. The effect of neighborhood poverty and residential mobility on child well-beling. Doctor of Philosophy, Ohio State University, Columbus, Ohio.

Harding, D., 2003. Counterfactual models of neighborhood effects: the effect of neighborhood poverty on high school dropout and teenage pregnancy. Am. J. Sociol. 109 (3), 676-719.

Haveman, R.H., Smeeding, T.M., 2006. The role of higher education in social mobility. Future Children 16 (2), 125-150.

Haveman, R.H., Wolfe, B., Spaulding, J., 1991. Childhood events and circumstances influencing high school completion. Demography 28 (1), $133-157$.

Heckman, J.J., 1990. Varieties of selection bias. Am. Econ. Rev. 80, 313-318.

Heckman, J.J., Hotz, V.J., 1989. Choosing among alternative nonexperimental methods for estimating the impact of social programs: the case of manpower training. J. Am. Stat. Assoc. 84 (408), 862-874.

Heckman, J.J., Ichimura, H., Todd, P., 1997. Matching as an econometric evaluation estimator: evidence from evaluating a job training programme. Rev. Econ. Stud. 64 (605-654).

Hedman, L., Van Ham, M., Manley, D., 2011. Neighbourhood choice and neighbourhood reproduction. Environ. Plann. A 43 (6), $1381-1399$.

Hendershott, A.B., 1989. Residential mobility, social support and adolescent selfconcept. Adolescence 24 (93), 217-232.

Hensen, M.M., de Vries, M.R., Cörvers, F., 2009. The role of geographic mobility in reducing education-job mismatches in the Netherlands. Papers Reg. Sci. 88 (3), 667-682.

Heylen, K., 2007. Residential mobility in Flanders: determinants of mobility and transition in housing tenure. Paper Presented at the ENHR Conference 'Sustainable Urban Areas, Rotterdam, the Netherlands.

Kambourov, G., Manovskii, I., 2009. Occupational mobility and wage inequality. Rev. Econ. Stud. 76 (2), 731-759.

Katz, L.F., Kling, J.R., Liebman, J.B., 2001. Moving to opportunity in Boston: early results of a randomized mobility experiment. Quart. J. Econ. 116 (2), 607654.

Kaufman, J.E., Rosenbaum, J.E., 1992. The education and employment of low-income black youths in withe suburbs. Educational Eval. Policy Anal. 14 (3), 229-240.

Kearns, A., Parkes, A., 2003. Living in and leaving poor neighbourhoods in England. Housing Stud. 18 (6), 827-851.

Keels, M., 2008a. Neighborhood effects examined through the lens of residential mobility programs. Am. J. Community Psychol. 42, $235-250$.

Keels, M., 2008b. Second-generation effects of Chicago's Gautreaux residential mobility program on children's participation in crime. J. Res. Adolescence 18 (2), 305-352.

Kling, J.R., Ludwig, J., Katz, L.F., 2005. Neighborhood effects on crime for female and male youth: evidence from a randomized housing voucher experiment. Quart. J. Econ. 120 (1), 87-130.

Larson, A., Bell, M., Young, A.F., 2004. Clarifying the relationships between health and residential mobility. Soc. Sci. Med. 59, $2149-2160$.

Ledoux, G., 2011. Prestaties en loopbanen van doelgroepleeringen in het onderwijsachterstandsbeleid. Almere Vandaag, 2.

Lee, V.E., Loeb, S., 1995. Where do head start attendees end up? One reason why preschool effects fade out. Educational Eval. Policy Anal. 17 (1), $62-82$.

Lee, B.A., Oropresa, R.S., Kanan, J.W., 1994. Neighborhood context and residential mobility. Demography 31 (2), 249-270.

Lu, M., 1998. Analyzing migration decision making: relationships between residential satisfaction, mobility intentions, and moving behaviour. Environ. Plann. A 30, 1473-1495.

Lucas, S.R., 2007. Unequal chances: family background and economic success. Contemporary Sociology: J. Rev. 36 (1), 26-28.

Machin, S., Pelkonen, P., Salvanes, K.G., 2012. Education and mobility. J. Eur. Econ. Assoc. 10 (2), 417-450.

Malamud, O., Wozniak, A., 2008. The impact of college graduation on geographic mobility: Identifying education using multiple components of Vietnam draft risk. IZA Working Papers. IZA Discussion Paper No. 3432.

McLanahan, S., Sandefur, G.D., 1994. Growing Up with a Single Parent: What Hurts, What Helps. Harvard University Press, Cambridge, MA.

Mendenhall, R., DeLuca, S., Duncan, G., 2006. Neighborhood resources, racial segregation, and economic mobility: results from the Gautreaux program. Soc. Sci. Res. 35 (4), 892-923.

MinVROM, 2000. Mensen, wensen, wonen: Wonen in de 21e eeuw. Technical Report. Ministry of Housing, Spatial Planning and the Environment. The Hague.

Morrison, D.R., Coiro, M.J., 1999. Parental conflict and marital disruption: do children benefit when high-conflict marriages are dissolved? J. Marriage Family 61 (626-637).

Myers, D., 1999. Cohort longitudinal estimation of housing careers. Housing Stud. 14 (4), 473-490.

Norford, B.C., Medway, F.J., 2002. Adolescents' mobility histories and present social adjustment. Psych. Schools 39 (1), 51-62.

Ommeren van, J., van Leuvensteijn, M., 2005. New evidence on the effect of transaction costs on residential mobility. J. Reg. Sci. 45 (4), $681-702$.

Oreopoulos, P., 2003. The long-run consequences of living in a poor neighborhood. Quart. J. Econ. 118, 1533-1575.

Pettit, B., McLanahan, S., 2003. Residential mobility and children's social capital: evidence from an experiment. Social Sci. Q. 84 (3), $632-649$.

Rabe, B., Taylor, M., 2010. Residential mobility, quality of neighbourhood and life course events. J. Roy. Stat. Soc. 173 (3), $531-555$.

Rodriguez, J.P., Rodriguez, J.G., Salas, R., 2008. A study on the relationship between economic inequality and mobility. Econom. Lett. 99, 111-114.

Rosenbaum, J.E., DeLuca, S., 2000. Is housing mobility the key to welfare reform? Lessons from Chicago's Gautreaux program. Brookings Inst. - Survey Ser., $1-9$

Rossi, P.H., 1955. Why Families Move: A Study in the Social Psychology of Urban Residential Mobility. Free Press, Glencoe, IL.

Sampson, R.J., Morenoff, J.D., Gannon-Rowley, T., 2002. Assessing neighborhood effects: social processes and new directions in research. Annu. Rev. Sociology 28, 443-478.

Sampson, R.J., Skarkley, P., Raudenbush, S., 2008. Durable effects of concentrated disadvantage on verbal ability among African-American children. Proc. Natl. Acad. Sci. 105, 845-852.

Sanbonmatsu, L., Kling, J.R., Duncan, G.J., Brooks-Gunn, J., 2006. Neighborhoods and academic achievement - results from the moving to opportunity experiment. J. Human Resour. XLI (4), 649-691.

Sanbonmatsu, L., Ludwig, J., Katz, L.F., Gennetian, L.A., Duncan, G.J., Kessler, R.C., Tessler Lindau, S., 2011. Moving to Opportunity for Fair Housing Demonstration Program - Final Impacts Evaluation. National Bureau of Economic Research, Cambridge, MA.

Schafft, K.A., 2006. Poverty, residential mobility, and student transiency within a rural New York school district. Rural Sociology 71 (2), $212-231$.

Sharkley, P., 2012. An alternative approach to addressing selection into and out of social settings: neighborhood change and African American children's economic outcomes. Sociol. Methods Res. 41 (2), 251-293.

Sharkley, P., Elwert, F., 2011. The legacy of disadvantage: multigenerational neighborhood effects on cognitive ability. Am. J. Sociol. 116 (6), $1934-1981$.

Shroder, M., 2001. Moving to opportunity: an experiment in social and geographical mobility. Cityscape: J. Policy Dev. Res. 5 (2), 57-67.

South, S.J., Haynie, D.L., Bose, S., 2007. Student mobility and school dropout. Soc. Sci. Res. 36, 68-94.

Speare, A., 1974. Residential satisfaction as an intervening variable in residential mobility. Demography 11 (2), 173-188. 
Speare, A., Goldstein, S., Frey, W.H., 1975. Residential Mobility, Migration and Metropolitan Change. Ballinger, Cambridge, MA.

Staff, J., Kreager, D.A., 2008. Too cool for school? Violence, peer status and high school dropout. Soc. Forces 87 (1), $445-471$.

Swanson, C.B., Schneider, B., 1999. Students on the move: residential and educational mobility in America's schools. Sociol. Educ. 72 (1), 54-67.

Sykes, B., Musterd, S., 2011. Examining neighbourhood and school effects simultaneously: what does the Dutch evidence show? Urban Stud. 48 (7), $1307-$ 1331.

Tucker, C.J., Marx, J., Long, L., 1998. ‘Moving on': residential mobility and children's school lives. Sociol. Educ. 71 (2), $111-129$.

Voight, A., Shinn, M., Nation, M., 2012. The longitudinal effects of residential mobility on the academic achievement of urban elementary and middle school students. Educational Researcher 41 (9), 385-392.

Werfhorst van de, H.G., 2002. A detailed examination of the role of education in intergenerational social-class mobility. Social Sci. Inform. 41 (3), 407-438.

Wodtke, G., Harding, D., Elwert, F., 2011. Neighborhood effects in temporal perspective: the impact of long-term exposure to concentrated disadvantage on high school graduation. Am. Sociol. Rev. 76 (5), 713-736.

Wood, D., Halfon, N., Scarlata, D., Newacheck, P., Nessim, S., 1993. Impact of family relocation on children's growth, development, school function, and behavior. J. Am. Med. Assoc. 270 (11), 1334-1338.

Wooldridge, J.M., 2003. Introductory Econometrics, 2 ed. Thomson - South Western, Mason, Ohio. 